Forest and Restoration Opportunities in the Panshet Catchment

\title{
Restoration Templates for Sahyadri (Northern Western Ghats)
}

\author{
Ketaki Ghate, Manasi Karandikar, Kirti Amritkar
}

Ketaki Ghate and Manasi Karandikar are co-founders and managing partners at oikos for Ecological Services, Pune. They are trustees and core team members at Ecological society and teach in the program. They have been on various government committees, written articles in popular media and papers in academic journals. Email: ketaki@oikos.in

Kirti Amritkar is associated with oikos for Ecological Services, and is a core member of Jeevitnadi Living River Foundation, Pune. She was employed as Project Officer in Maharashtra State Environment Department from 20082013.

\begin{abstract}
Sahyadri mountains are witnessing a great change in land use pattern and lifestyle of local people over the last few decades because of modern development and construction of dams. As a result ecological systems within the catchment have changed resulting in a change in socio-economic conditions. The usual approach to tackle this situation is plantation or afforestation. However, this approach does not consider the revival of ecosystems. As mitigation measures, the Ecological Society, in 1986, had conducted experiments in the Panshet dam catchment. This resulted in the development of restoration methods for the bioclimatic region of Sahyadri. The approach of this experiment was using a low-cost restoration methodology. In this, enhancement of the ecosystem in early stages of restoration provides ecosystem services and products, such as fodder in the intermediate stage to the local communities. By using similar techniques, oikos for ecological services, a company engaged in ecological restoration, undertook several ecological restoration programs on private lands within the Sahyadri region. The results showed significant improvement in ecosystems and biodiversity, thereby improving livelihood options for the local communities.

Funded by a grant from Global Forest Watch, Ecological Society conducted an assessment of changes in land use and status of biodiversity in Panshet, in 2014-15. The Panshet dam catchment forms a part of Sahyadri and similar conditions are encountered elsewhere in the region. This study made an assessment of the potential for restoration in the catchment area. Based on this study and earlier studies by oikos for ecological services, we created templates which are intended to guide restoration process of degraded lands in Sahyadri.

The templates are backed by the experience of actual implementation of restoration techniques on various land patches within Sahyadri during the last 30 years. Three templates are presented to guide the complete process of restoration.
\end{abstract}

Keywords: Ecological restoration, Restoration templates, Sahyadri, Northern Western Ghats.

\section{Introduction}

Under undisturbed conditions, the physiography and climate of the Northern Western Ghats, locally known as the Sahyadri mountains, should support a tropical semi evergreen forest on the crest line and a moist deciduous forest on its eastern spurs in the 'climax' state of vegetation (Champion and Seth, 1968). However, the present condition of these forests is variedly degraded and fragmented due to human use for cultivation, commercial gains, dams. For example, in the case of Panshet dam near Pune, there are significant changes in the river basin and in community use of the available resources, because of the construction of the Panshet dam. The villages in the catchment area have been shifted to higher contours, where they practice slash and burn farming (Gole, 1985). This type of shifting cultivation has turned all the forested slopes to secondary vegetation. Moreover, contractors who buy timber from the local people either for making coal or selling as timber, have triggered the clearing of forested slopes in this region. In the last few years' farm house townships have attracted urban attention and this has put severe 
pressure on the natural setting of the catchment. By extensive use of earth moving equipment, the land use has changed rapidly and further degraded the landscape. The present state of the landscape of Western Ghats is the outcome of years of use by local people and the modern developmental pressures within the last few decades (Ghate, 2014). The original forest cover and biodiversity of the NWG, now remains only in some pockets of notified protected areas and within semi-protected areas like sacred groves. The rest of the landscape is degraded to various seral stages depending on the degree of disturbance, mainly due to socio-economic changes in the catchment (Ghate, 2014). Therefore, there is an immediate need to conserve and restore these ecosystems towards better health of the landscape benefitting human as well as non-human beings.

As a solution to address this degradation, efforts are usually put in plantation or afforestation to increase biotic resources needed by the local community and to improve ecosystem. However, plantations cannot be affordable and feasible over a large expanse like the NWG. Moreover, plantations do not consider a landscape approach nor the revival of ecosystems. Plantations are effective when undertaken on smaller areas where the landscape is in a degraded state. Ecological society has developed restoration methods where low cost passive restoration techniques can be employed. This requires protection of the area and undertaking certain interventions. These are planned for ecological restoration at a landscape level. During this experimentation, Ecological Society (ES) has developed a framework for restoration.

During any restoration project, especially in the Northern Western Ghats (NWG) some important aspects must be considered. These are (i) 'fragility of ecosystem' due to very high rainfall along the crest line (ii) catchment of some of the major rivers in the Indian peninsula (iii) physical conditions (abiotic conditions) and forests (biotic resources) at the river source regions (iv) these are the major soil producing areas, supplying soil downstream. All these special physical features have created unique habitats which have been supporting biodiversity some of which are unique to the habitat, that is endemic species. In this situation, the biodiversity and ecosystems are extremely important and precious. (Ghate, 2014)

\section{Background}

The restoration templates are intended to offer a process guide to help users plan and take decisions based on the collected data. Moreover, they also specify what data needs to be collected. For a given bioclimatic region, restoration techniques may remain fairly similar. The actual process of nature restoration involves a trial and error approach. Thus, learning from earlier restoration experiments may help to follow process of restoration.

These templates are developed based on experimentations conducted in 30 long years, starting with an assessment of biodiversity of Panshet Catchment, in 1985. This survey showed a deficient resource situation in this region. Due to the dam construction, several villages were displaced to higher contours. Thus, the villagers had poor access to water and got less fertile land for cultivation and consequently faced livelihood issues. Earlier, their lifestyle was dependent on natural resources, but as the forests degraded, bio-resources grew scarce in the changed situation. In 1986, ES undertook an experiment on a barren hill slope owned by the Irrigation department, Maharashtra State. A three-year restoration exercise was initiated at this site. The idea of creating templates originated in this experiment. Subsequently, the experience gained from projects carried out by oikos for ecological services at others sites in the NWG and other bioclimatic zones of India, helped shape the templates. The templates have been benefited from the insights gained in the ongoing project within Koyna catchment in NWG, since the last 10 years. This project is a pure conservation approach towards restoration. Similarly, oikos undertook restoration planning for 16 sacred groves in Palghar district (earlier Thane district) where, actual implementation was done in two sacred groves over three years. The community was involved in the restoration. Over the last 15 years, oikos has applied restoration principles in over 100 commercial projects. For example, in an eco resort on 300 acre near Bangalore more than $70 \%$ of the land is dedicated for conservation and restoration. This experience and observations of various ecosystem stages at landscape level over the years has helped in the making of templates proposed herewith. We expect these templates to help in identifying problems, collecting right data, following the right procedures and consequently save time and inputs to restoration practitioners. They can be used to assess current conditions before making a choice of appropriate restoration technique. The templates can be used for restoration work in bioclimatic zones similar to that of Sahyadri.

After a review of literature available on restoration templates and discussions with experts, it was seen that most of the existing templates have evolved for 
watershed development or stream restoration (Dept of Environmental Protection, 2004). Moreover, in many of the templates, the focus is to restore physical attributes, control erosion, or stop pollution. It was also seen that the templates lacked the consideration of biotic components in them. Our experience suggests that biodiversity can be used as an indicator to judge the present state of the land and then design a restoration strategy. Thus, our approach towards restoration starts with an assessment of physical conditions and biotic components. This article describes the templates and explains their use.

The Society for Ecological Restoration (SER) USA, an organization promoting ecological restoration, has developed a set of guidelines for developing and managing ecological restoration projects. The first edition discusses various terms used in restoration ecology, importance of assessing reference ecosystems and non-native species along with guidelines to set restoration objectives and design planning (Science and Policy Working Group , 2004). The second edition focuses on planning and implementation tasks. SER suggests preliminary tasks like appointment of a restoration practitioner and a team, documentation of history of the site, establish reference ecosystem, defining goals and liasoning with public agencies. Implementation planning and tasks include description of each intervention, scheduling, marking boundaries, installing permanent fixtures followed by post-implementation tasks for effective monitoring and evaluation of the project (Clevell, Rieger, and Munro, 2005). These guidelines seem to be useful in technical planning of the project but do not provide restoration activities.

\section{Restoration potential analysis}

Before undertaking any restoration program, it is important to assess the restoration potential of the area surrounding the selected site. This is because the site is connected to a larger landscape through flows of surface and ground water, exchange of nutrition, seeds and through wind and water and movement of fauna. The restoration potential analysis conducted in the Panshet dam catchment in the NWG is discussed ahead.

\section{Restoration potential analysis for Panshet catchment: A Case study}

For undertaking an assessment of the restoration potential, the following steps were taken.

1. A satellite image of the selected area was used to examine the land use and assess the vegetation.
2. The identified land use and vegetation was divided into classes and a map was prepared from this.

3. To validate these classes and locations, ground truthing was undertaken in sample areas.

4. The quality of the vegetation classes was decided by the species composition and the occurrence of endemic species or habitat specialist or locally rare species. This established the level of degradation and the potential for restoration in this area.

Based on the above analysis, the restoration was prioritized into four categories.

$\begin{array}{lllrl}\text { No } & \begin{array}{l}\text { Restoration } \\ \text { Priority }\end{array} & \text { Vegetation class } & \text { Area } & \text { \% } \\ 1 & \text { Priority 1 } & \text { Mature forest } & 2922.10 & 11 \\ 2 & \text { Priority 2 } & \text { a.Dwarf canopy } & 10113.36 & 40 \\ & & \text { b.Scrub } & 6427.13 & 25 \\ 3 & \text { Priority 3 } & \text { Open grasslands } & 3268.13 & 12 \\ 4 & \text { Priority 4 } & \text { Human use } & 3027.16 & 12 \\ & & \text { Total } & 25757.88 & 100\end{array}$

The table shows priorities towards conservation and restoration. Mature forests which have endemic biodiversity are the first priority for conservation. These include all sacred groves and some inaccessible areas. If not fully protected, species within these areas may get wiped out from the entire catchment.

The map shows that there are three major vegetation classes in the catchment. These classes are defined on vegetation character indicating degrees of degradation. There is a potential for restoration in vegetation class with the second priority. These are degraded forests but can be improved relatively fast. In the Panshet catchment, remnants of earlier forests are still seen sporadically. Root stock in such areas help in faster restoration than totally barren areas or grasslands.

Grasslands being a totally different habitat than forests, will take longer time to restore. Also are assigned a lesser priority for restoration as forest endemic species are already lost from these areas.

Finally, though it appears that land under human use is minimal, there is substantial use of the land around these areas for activities such as grazing, fuel wood and shifting cultivation. Mature forest areas like Sacred Groves are also threatened due to developmental activities around them and human interventions inside grove. Also, practices like lighting fires, put severe stress on the landscape. Similarly, the 


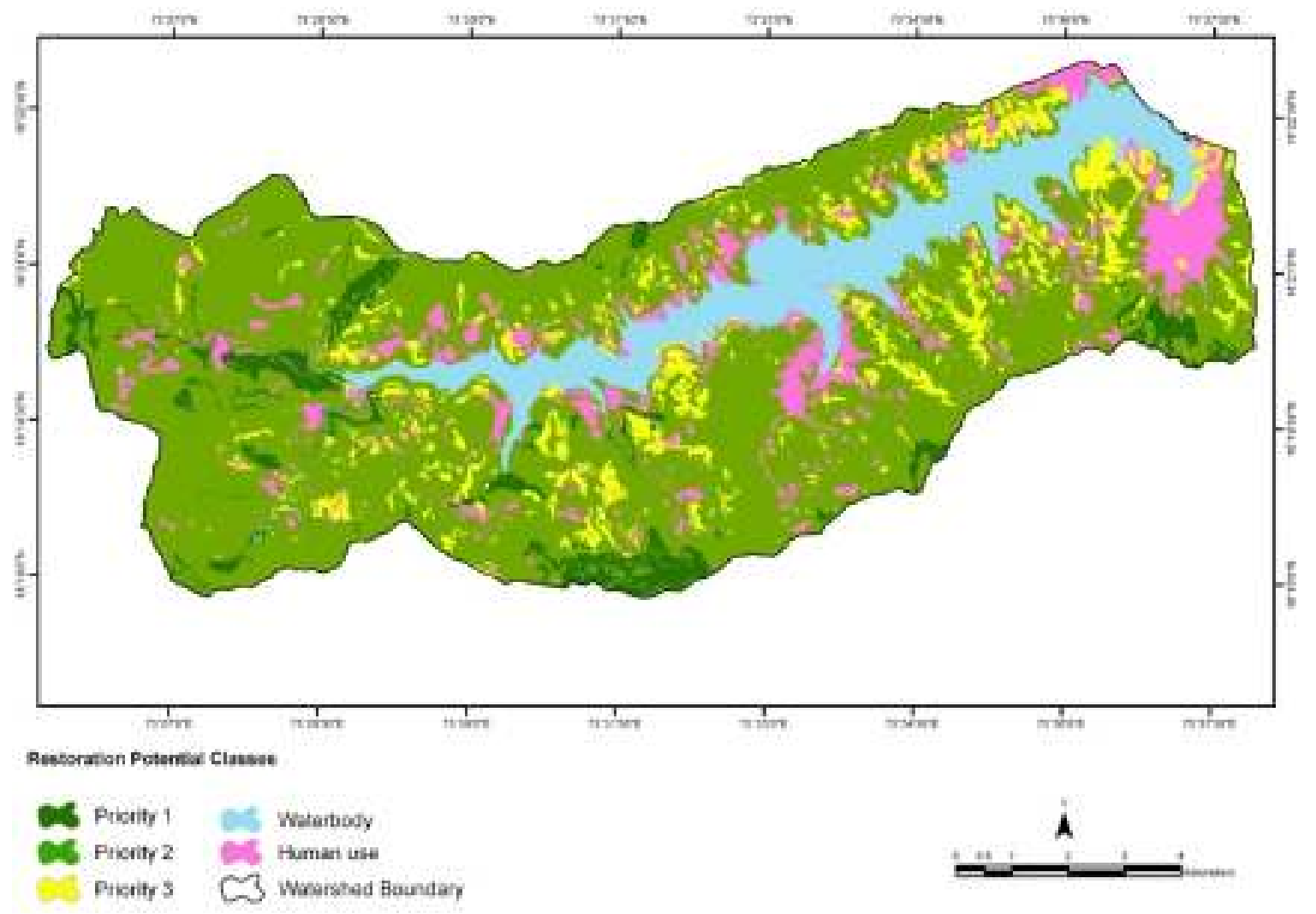

potential future threats of new settlements owned by urban people like farm houses are visible in the map, must be considered. Hill slopes are fenced, leveled and plotted for modern development. All these land classes can be restored by using restoration techniques discussed below.

\section{Restoration template}

The entire Sahyadri has composition and landscape similar to Panshet dam catchment, therefore we have used this study as a canvas to propose restoration template for entire region. Based on experimentation carried out over the years, Ecological Society has suggested restoration techniques which can be used to restore this variedly degraded landscape. The concept of nature restoration is now gaining popularity and its benefits are tangible. Thus, the authors propose templates in this paper which can be used by various stakeholders. These templates comprise restoration techniques as illustrated further in a Table 1. However, the techniques need to change as per the starting point or site specific conditions or current status of the land under consideration.

These templates are designed using two approaches:
1. Pure conservation approach where efforts are directed towards restoration of climax forest, for the sole purpose of restoring natural resources, biodiversity and ecosystem services. Refer Table 2. Various stakeholders like government departments like forest and irrigation departments, village commons, private parties and others can consider this approach. Government departments can implement this for land owned by the forest department, lands considered for compensatory afforestation programmes or the land which is going to be unused for next few decades. Local farmers may not use this approach but urban citizens owning farm house plots would find this approach useful, since they are not dependent on land for their livelihood. With this approach, they can give back to nature. To a certain extent, a part of village common land can be restored with this approach considering long term benefits and ecosystem services being offered to future generations in terms of water or fertility of soil, or pollinating services etc.

2. Integrated approach: Restoration to strengthen natural resources to support livelihood of local people. Refer Table 3. This approach is intended 
Table 1: Steps in Restoration

\begin{tabular}{|c|c|c|}
\hline No. & $\begin{array}{l}\text { Restoration } \\
\text { technique }\end{array}$ & Details \\
\hline 1 & Protection & $\begin{array}{l}\text { Total protection from cutting of vegetation, cattle and fire is the first step. The same can } \\
\text { be achieved with dry fence and live hedge. Identification and protection of safe sites. }\end{array}$ \\
\hline 2 & $\begin{array}{l}\text { Soil and } \\
\text { moisture } \\
\text { conservation }\end{array}$ & $\begin{array}{l}\text { Erosion-prone areas or slopes needs to be worked on with the help of local materials } \\
\text { like stones and boulders to arrest soil and reduce water velocity. }\end{array}$ \\
\hline 3 & $\begin{array}{l}\text { Vegetation } \\
\text { management }\end{array}$ & $\begin{array}{l}\text { Protection to existing flora, stage wise natives plantation (initially hardy plants and } \\
\text { then desired plants), removal of invasive non-natives etc. }\end{array}$ \\
\hline 4 & $\begin{array}{l}\text { Habitat } \\
\text { creation }\end{array}$ & $\begin{array}{l}\text { Creation of rock piles, log piles, wetlands, plantation of larval host plants, shrub } \\
\text { clusters etc. }\end{array}$ \\
\hline 5 & $\begin{array}{l}\text { Plantation } \\
\text { (Native plants) }\end{array}$ & Selecting appropriate native plants as per the current status of the soil and land. \\
\hline 6 & $\begin{array}{l}\text { Seed dispersal } \\
\text { (Native plants) }\end{array}$ & $\begin{array}{l}\text { One of the easiest ways to introduce native plants and test regenerating capacity of } \\
\text { the soil. }\end{array}$ \\
\hline
\end{tabular}

* Photographs: oikos for Ecological Services 
Table 2 : Conservation approach

\begin{tabular}{|l|l|l|l|l|l|l|}
\hline $\begin{array}{l}\text { Current status } \\
\text { of land } \rightarrow\end{array}$ & Grasslands & $\begin{array}{l}\text { Scrub } \\
\text { canopy }\end{array}$ & $\begin{array}{l}\text { Shrubbery } \\
\text { canopy }\end{array}$ & $\begin{array}{l}\text { Dwarf } \\
\text { forest }\end{array}$ & Tall & Mature \\
$\begin{array}{l}\text { Restoration } \\
\text { techniques }\end{array}$ & $\begin{array}{l}1,2,3,4, \\
5,6\end{array}$ & $\begin{array}{l}1,2,3,4, \\
5,6\end{array}$ & $1,3,5,6$ & $1,5,6$ & $1,5,6$ & $\begin{array}{l}\text { End point : } \\
\text { evergreen } \\
\text { Forest }\end{array}$ \\
$\begin{array}{l}\text { Approximate } \\
\text { time frame (yrs) }\end{array}$ & $15-20$ & $10-12$ & $10-15$ & $10-15$ & $20-50$ & \\
\hline
\end{tabular}

* Please note: The time frame is based on observations of local people and team along with the restoration experiment carried out by Ecological Society at Panshet catchment. It is subject to variation.

** Treatment to a special habitat in Sahyadri: 'Rocky outcrop' Habitat: Sahyadri have a special type of rocky habitats shaped due to Lateritic outcrop or Basalt outcrop. Here, scarcity of soil and harsh physical conditions lead to formation of vegetation community dominated by grasses and herbaceous flora along with habitat-specialist amphibians and reptiles (Watve, 2010). These being very special ecosystems and host special endemic species. Therefore they must be protected completely from any human interference. Considering the high degree of endemism in biodiversity, it is suggested to have no intervention on this land class. Using the first technique in table 1, i.e. protection is recommended and plantations or using other restoration techniques are not recommended in this habitat.

** Special Sites : Existing patches of Protected Mature forests also should be excluded from any interference and be treated as special sites. These may include sacred groves, inaccessible areas, rock fall areas, few government owned mature forest patches etc. All such sites need just first technique i.e. protection as in table 1. But if at all any kind of interference or degradation is seen, appropriate measures to be selected based on above template.

Table 3 : Integrated approach

\begin{tabular}{|c|c|c|c|c|}
\hline \multirow[b]{2}{*}{ No. } & \multirow[b]{2}{*}{ Restoration technique } & \multicolumn{3}{|c|}{ Starting point } \\
\hline & & Grasslands & Scrub & Dwarf Canopy \\
\hline & & $\begin{array}{l}\text { Management for } \\
\text { fodder }\end{array}$ & & $\begin{array}{l}\text { Management for } \\
\text { fuel wood }\end{array}$ \\
\hline 1 & Protection & $\checkmark$ & $\checkmark$ & $\checkmark$ \\
\hline 2 & Soil and moisture conservation & $\checkmark$ & $\checkmark$ & \\
\hline 3 & Vegetation management & $\checkmark$ & $\checkmark$ & \\
\hline 4 & Habitat creation & $\checkmark$ & $\checkmark$ & $\checkmark$ \\
\hline \multirow[t]{2}{*}{5} & Plantation & & & $\checkmark$ \\
\hline & & \multicolumn{3}{|c|}{ End point : Livelihood support } \\
\hline
\end{tabular}

*This approach does not include Tall or Mature Canopy forest patches as such patches have to be protected and conserved as it is. 
to address needs of local people living in these mountains for generations and use the local resources for their livelihood. When the population was lower, resources were enough to suffice their needs and they could survive without land management. But the increasing population, changing life style and resources depletion, there is an immediate need for land management and nature restoration, so that they can be used sustainably in future. In this approach, the objective is to improve landscape and maintain it in a better condition so that communities will get benefits of from the various ecosystem services and products.

In both the templates, operational techniques remain the same.

Restoration template for data monitoring useful for Implementation

Measuring the key indicators mentioned below will help track the path of the restoration effort. Often the direction of restoration may be subject to nature's vagaries, local climatic effects, and impacts of human interference. Monitoring these indicators will help in judging the interventions needed to keep restoration on the desired path.

\section{Additional Tips for Ecological Restoration (Gole, Restoration of Nature, 2007)}

- When the work of ecological restoration begins on a given area, total protection is the key factor and local community awareness regarding this initiative is also important.

- A detailed survey of the existing floral and faunal species and its documentation is necessary. It is useful as base line data during future stages of restoration.

- Identification of reference sites like Sacred Grove or mature forest patch nearby the project area will help in understanding composition of climax stage

\begin{tabular}{|c|c|c|c|c|c|}
\hline & \multirow[t]{2}{*}{ Indicator } & \multirow[t]{2}{*}{ Details } & \multicolumn{3}{|c|}{ Year wise data } \\
\hline & & & Year 1 & Year 2 & Year 3 \\
\hline \multirow[t]{2}{*}{ A } & Biomass & & & & \\
\hline & Increase in biomass & Dry and wet biomass of grasses & & & \\
\hline \multirow[t]{5}{*}{ B } & Overall biodiversity & & & & \\
\hline & $\begin{array}{l}\text { Increase in habitat } \\
\text { diversity }\end{array}$ & $\begin{array}{l}\text { Grassy areas : Shrub Clusters : Tree } \\
\text { clusters : Instream habitats* : Wetlands }\end{array}$ & & & \\
\hline & $\begin{array}{l}\text { Index of diversity - } \\
\text { June }\end{array}$ & $\begin{array}{l}\text { Number (flora-fauna species) to be } \\
\text { recorded from each habitat }\end{array}$ & & & \\
\hline & $\begin{array}{l}\text { Index of diversity - } \\
\text { September }\end{array}$ & $\begin{array}{l}\text { Number (flora-fauna species) to be } \\
\text { recorded from each habitat }\end{array}$ & & & \\
\hline & $\begin{array}{l}\text { Improvement in } \\
\text { biodiversity }\end{array}$ & $\begin{array}{l}\text { Ratio of 'Species indicating degradation : } \\
\text { Species indicating improvement' }\end{array}$ & & & \\
\hline \multirow[t]{8}{*}{ C } & $\begin{array}{l}\text { Soil and moisture } \\
\text { conservation }\end{array}$ & & & & \\
\hline & Soil quantity arrested & & & & \\
\hline & Soil pH & & & & \\
\hline & Soil temperatures & & & & \\
\hline & Soil carbon & & & & \\
\hline & Water recharge capacity & & & & \\
\hline & Conductivity & & & & \\
\hline & Moisture monitoring & Thrice a year & & & \\
\hline
\end{tabular}




\begin{tabular}{|c|c|c|c|c|c|}
\hline & \multirow[t]{2}{*}{ Indicator } & \multirow[t]{2}{*}{ Details } & \multicolumn{3}{|c|}{ Year wise data } \\
\hline & & & Year 1 & Year 2 & Year 3 \\
\hline \multirow[t]{8}{*}{$\mathrm{D}$} & Vegetation & & & & \\
\hline & $\begin{array}{l}\text { Change in \% of cover } \\
\text { types }\end{array}$ & $\begin{array}{l}\text { Ratio of No-vegetation : grass : } \\
\text { shrub : tree }\end{array}$ & & & \\
\hline & Revival of shrubs & $\begin{array}{l}\text { Average height and width of } \\
\text { monitored clumps }\end{array}$ & & & \\
\hline & Natural regeneration & $\begin{array}{l}\text { Number and species of regenerated } \\
\text { saplings within quadrats }\end{array}$ & & & \\
\hline & $\begin{array}{l}\text { Increase in herbaceous } \\
\text { flora }\end{array}$ & $\begin{array}{l}\text { Species and Status : Common, } \\
\text { Few, Rare }\end{array}$ & & & \\
\hline & $\begin{array}{l}\text { Change in Grass } \\
\text { community }\end{array}$ & $\begin{array}{l}\text { Composition of grasses, } \% \text { area } \\
\text { covered by each species }\end{array}$ & & & \\
\hline & Overall plant list & & & & \\
\hline & $\begin{array}{l}\text { Survival of saplings } \\
\text { during dry season and } \\
\text { their height. }\end{array}$ & Lists along with numbers & & & \\
\hline \multirow[t]{5}{*}{$\mathrm{E}$} & Habitat Improvement & & & & \\
\hline & Safe site development & $\begin{array}{l}\text { Safe sites for special plant, } \\
\text { Nesting of birds, Webs of spiders, } \\
\text { insect diversity and population etc. : } \\
\text { Lists of species and numbers } \\
\text { within quadrats }\end{array}$ & & & \\
\hline & $\begin{array}{l}\text { Improvement in } \\
\text { microclimate }\end{array}$ & $\begin{array}{l}\text { Ambient Temp and humidity readings : } \\
\text { Open areas and Shady areas }\end{array}$ & & & \\
\hline & Associations & $\begin{array}{l}\text { Plants : Plants } \\
\text { Flora : Fauna } \\
\text { e.g. Butterflies - Foodplants }\end{array}$ & & & \\
\hline & Habitat interactions & $\begin{array}{l}\text { Habitat listing and observing } \\
\text { interactions within habitats. } \\
\text { e.g. wetland and nearby shrubbery }\end{array}$ & & & \\
\hline $\mathrm{F}$ & Map of project land & & & & \\
\hline
\end{tabular}

* Instream habitats like pools, riffles, bars etc.

ecosystem and developing seed bank of native plant species.

- Removal of any kind of pre-existing native vegetation is not advised. Whatever vegetation cover exists is useful for conserving moisture as it adds biomass and casts shade.

- When it comes to removal of non-natives, experts should be involved.
- In the application of restoration techniques, if biomass is externally added to the site - documentation of observations regarding species growing on such area is necessary. It will help in deciding repetition of such intervention.

- If possible, create small wetlands/ponds in the area as it will add to the habitat diversity. It will help improving the micro climate. 
- One can plan to have habitat diversity in the given area; e.g. Patch of scrub and grassland and clumps of trees, etc. In case of wetlands, shallow sheet of water, sand flats, islands, dykes can be considered. This will help in increasing biodiversity.

- Documentation of special observations is necessary to understand the trend of the restoration stages. e.g. Excessive growth of certain herbs along the path or hedges indicating disturbances to some extent, occurrence of specialist species, flocks of certain species of bugs and beetles.

\section{Limitations of the template :}

1. The templates proposed may not be enough for a completely changed land use or degraded landscape like mining areas where hardly any mosaic of habitat is retained. In such a case, simple protection and creation of physical features may not get quick results in revival of biodiversity. Here active restoration techniques are recommended, where use of external materials and energy is involved. We recommend one important active technique of addition of biomass to the land so that soil processes can be initiated along with other techniques mentioned in the template like creation of ponds and introduction aquatic plants etc.

2. The same strategy can be applied where grasslands stage is arrested due to edaphic factors. Due to degradation, soil loss is so heavy that rocks get exposed and so no biomass is available as a raw material for restoration calling for active restoration techniques.

\section{Significance of restoration templates}

The above restoration templates may help various stakeholders like forest department, irrigation department, or private land owners who own large land parcels in Sahyadri. Often, these land parcels can be ecologically improved, but are neglected due to lack of awareness and knowledge of restoration techniques. With the help of clear understanding of current status and using these restoration templates, it is possible to undertake planning and implementation of restoration. However, we suggest involving experienced ecologists for planning and execution.

These templates would be useful for large scale restoration of fragmented landscapes which need to be preserved for their ecosystem services. For example, Sahyadri mountains are source regions for many rivers supplying water to the Indian peninsula, and therefore needs to be preserved for sustainable use.

Institutes like World Resources Institute (WRI) and Global Forest Watch (GFW) are working towards restoration at landscape level. In the last few years, several countries have been undertaking restoration of deforested and degraded forest landscapes in their own countries. The global Bonn Challenge, launched in 2011, calls for the restoration of 150 million hectares by 2020 . As a response to this, WRI, International Union for Conservation of Nature (IUCN) and the University of Maryland created an Atlas of Forest Landscape Restoration Opportunities. This is a coarsescale map of the potential forest restoration opportunities globally.

Restoration is expected to create significant employment opportunities at local scale in tropical countries like India. Considering the paucity of information and methodologies available for restoration, the authors expect that the templates suggested here would be of practical use. The authors acknowledge the scope for improvement of these templates and invite practitioners to use them and provide feedback.

\section{References}

Champion, H. G., and Seth, S. K. (1968). A revised survey of Forest types on India. Govt of India Press.

Clevell, A., Rieger, J., and Munro, J. (2005). Guidelines for developing and managing ecological restoration project, 2nd Edition.

Dept of Environmental Protection. (2004). The watershed restoration template. Pennsylvania Department of Environmental Protection and the Canaan Valley.

Ghate, K. (2014). Management of forests in Northern Wetsren Ghats. Journal of ecological Society, Vol. 2627.

Gole, P. (1985). An Enquiry into the status of animal and plant life in critical areas of Western Ghats in order to evolve a plan to conserve their biological diversity. Ecological Society.

Gole, P. (2007). Restoration of Nature. Ecological Society.

(2015). Report of Ecological Survey undertaken in Panshet Catchment under Small Grants Program (Global Forest Watch). Ecological Society.

(2004). SER International Primer on Ecological Restoration, Science and Policy Working Group (Version 2). Society for ecological Restoration.

Watve, A. (2010). Rocky Plateaus. WGEEP. 